\title{
Las Nuevas Fronteras del Cine Documental: la Producción de lo Real en la Época de la Imagen Omnipresente
}

\section{The New Boundaries of Documentary Cinema: the Production of Realness in Times of an Omnipresent Image}

\author{
Juan Carlos Arias \\ Universidad Javeriana de Bogotá \\ ariasjuanc@hotmail.com
}

Resumen • El término «documental», aplicado al audiovisual, parece volverse cada día más ambiguo. Hoy es posible encontrar tantas taxonomías y géneros dentro de lo que se llama cine documental como películas «documentales` se producen. Una cosa, sin embargo, parece seguir siendo clara: el documental es lo otro con respecto a la ficción. Por lo menos este es el a priori perceptivo que sigue funcionando entre los espectadores y que legitima una imagen como 〈documentals: se supone, de antemano, que las imágenes son verdaderas con respecto al mundo que les dio origen. El objetivo básico de este texto es proponer la perspectiva ético-política como el punto de vista desde el cual puede pensarse hoy la división-yuxtaposición de documental y ficción. Dados los múltiples cambios que han afectado al cine documental, hoy la frontera que lo separa de la ficción, y que lo define como tal, se establece desde una reflexión ético-política relacionada directamente con la figura del autor y la construcción de realidad en la imagen.

Palabras clave: Documental, ficción, montaje, realidad.

Abstract - The word «documentary», applied to the audiovisual field, seems to be increasingly ambiguous. Nowadays, it is possible to find many taxonomies and genres within what is called documentary film as «documentaries» are produced. Nevertheless, something seems to remain clear: the documentary is in opposition to the so-called fiction films. At least, this is an a priori perception still operating among the spectators, warranting an image as «documentary»: it is assumed that the images are real in relation to the world that has created them. The main objective of this article is to propose an ethical/political perspective in order to think the division and juxtaposition of fiction and documentary. Today, with the many transformations that have affected documentary cinema, the frontier that separates it from fiction, is defined by this ethical/political thought related to the notion of aauthor and the construction of the real thing inside an image.

Keywords: Documentary, fiction, editing and mounting, reality. 


\section{PLANTEAMIENTO DEL PROBLEMA}

El término «documental», aplicado al audiovisual, parece volverse cada día más ambiguo. Hoy es posible encontrar tantas taxonomías y géneros dentro de lo que se llama cine documental como películas «documentales» se producen. Desde las divisiones temáticas más simples (documental político, ecológico, científico) hasta las más complejas relacionadas con el grado de intervención y participación del autor (documental directo, reflexivo, etc.); con la perspectiva de saberes de la que se parte (documental antropológico, sociológico, etc.); pasando, incluso, por las siempre útiles clasificaciones históricas, el documental es hoy un terreno cuyos límites parecen diluirse. Latinoamérica, evidentemente, no es la excepción.

Autores como Jorge Ruffinelli han realizado importantes aportes al panorama del documental latinoamericano contemporáneo construyendo una amplia descripción de las corrientes de las últimas dos décadas, partiendo de una línea de desarrollo iniciada en los años sesenta con películas de evidente tendencia política y social. Ruffinelli destaca algunas de las tendencias del documental hoy a partir de una "clasificación» desde su intencionalidad y estilo. De esta manera, recoge películas dentro de una corriente histórica de recuperación y reconstrucción del pasado - muchas veces marcado definitivamente por el dolor de los regímenes dictatoriales- que intenta crear un mapa de acontecimientos faltantes en la memoria de nuestros pueblos. Ésta, sin embargo, no es la única tendencia existente. De hecho, ni siquiera puede hablarse de una corriente única que parte de la intención de reconstruir el pasado. Ruffinelli muestra cómo dentro de esta gran línea pueden observarse diversos estilos y enfoques que varían la perspectiva sobre el problema de la memoria. Así, diferencia, por ejemplo, el documental «forense» de los documentales de investigación, distinguiendo la perspectiva asumida por el autor y los dispositivos particulares a través de los cuales se recrea la realidad.

Ahora bien, al lado de esta gran línea que tiende hacia la historia de «los nuestros» pueden encontrarse otras tendencias del documental más cercanas a la experimentación con la forma y la narración audiovisual, y a la hibridación con otros lenguajes expresivos. Así, el documental subjetivo con películas como La fe en el volcán de Ana Poliak y Papá Iván de María Inés Roqué; el documental piquetero con Compañero piquetero - de autoría colectiva-; o películas que Ruffinelli opta por no categorizar como Rocha que voa de Eric Rocha y Los rubios de Albertina Carri, muestran un complejo panorama en el cine latinoamericano que complejiza la posible formulación de una tendencia única del documental hoy.

El documental latinoamericano se muestra, de esta manera, como un complejo territorio en el que convive una multiplicidad de estilos y lenguajes. Ahora bien, hoy este territorio ya no preexiste a sus particulares habitantes, sino que son éstos los que, desde sus diversas perspectivas, reformulan permanentemente los límites del espacio habitado, el cual aún, quizás por costumbre, llamamos «documental».

Las causas de este hecho no son menos complejas que el hecho mismo. Diversos autores han afirmado la influencia de factores relacionados con las transformaciones de la realidad de los países latinoamericanos, así como la importancia de los cambios, cada vez más abruptos, en los elementos de producción definidos por las industrias y, sobre todo, por los desarrollos tecnológicos. 
Una cosa, sin embargo, parece seguir siendo clara: el documental es lo otro con respecto a la ficción, al llamado cine argumental. Por lo menos este es el a priori perceptivo que sigue funcionando entre los espectadores y que legitima una imagen como «documental»: se supone, de antemano, que las imágenes son verdaderas con respecto al mundo que les dio origen. El espectador prepara su mirada para acceder al mundo a través de la imagen, y no para sumergirse en una realidad fantástica que solo encuentra su ser en la imagen misma. De esta manera, no sólo la percepción del público sino el pensamiento teórico sobre el cine documental, han tomado como referente su distancia —radical o diluida - respecto a la ficción.

El objetivo básico de este texto es preguntarse por la frontera entre documental y ficción desde la particularidad de nuestra época. En primer lugar, examinaré dos posturas teóricas desde las cuales se ha intentado definir, hasta hoy, la diferencia entre el argumental y el documental: la ontología y el lenguaje. Mi interés radica en señalar la imposibilidad de asumir totalmente una de estas perspectivas dentro del panorama del audiovisual contemporáneo. Éste será, precisamente, el objeto de la segunda parte del texto: describir la particularidad de nuestra época a partir de un fenómeno concreto, la omnipresencia de la imagen. A partir de ésta propondré, en una última parte, una tercera opción para la comprensión de la particularidad de la imagen documental según la cual el documental encuentra una especificidad en tanto hace evidentes sus mecanismos de construcción de realidad a través del montaje.

\section{DOS PERSPECTIVAS SOBRE LA FRONTERA DOCUMENTAL-FICCIÓN: ONTO- LOGÍA Y LENGUAJE}

La división entre documental y argumental ha sido siempre compleja y problemática. Quizás la mejor muestra sean las múltiples discusiones, en cierto ámbito de la historia y teoría del cine, acerca de la naturaleza documental o argumental de las primeras películas de los Lumière. Ahora bien, considero que este tipo de discusiones orientadas a definir, directa o indirectamente, los límites entre la realidad documental y la ficción argumental, han estado sustentadas por dos perspectivas: una ontológica, basada en cierta relación entre imagen y realidad; y una de lenguaje, basada en las particularidades de la gramática audiovisual.

La primera de ellas, la perspectiva ontológica, reúne todas aquellas posturas que afirman que la frontera entre documental y ficción radica en su relación con lo real. Así, mientras en el documental se produce una relación directa entre la imagen y la realidad, en la ficción se crea una deformación subjetiva del mundo real. Esto implicaría que el documental se define principalmente por su relación inmediata con lo real, por su capacidad objetiva y representativa. En él, existe un claro referente exterior que legitima el valor de las imágenes, precisamente como documento de la realidad. El espectador tendría, de esta manera, la certeza de que, aparte de las imágenes, existe un objeto real independiente de ellas que posibilitó su existencia. Lo que se ve sucedió realmente en algún momento y lugar. La imagen adquiere consistencia como testimonio material gracias a los acontecimientos exteriores a ella misma, de la misma manera que estos últimos encuentran en 
la imagen un espacio de representación, divulgación y memoria. Lo real se erige de esta manera como el soporte ontológico de la imagen dándole un carácter de verdad.

Desde esta perspectiva, la ficción, referida a la construcción de realidades, se mostraría como lo opuesto al cine documental, el cual se caracterizaría por asumir una realidad que ya está dada para dar cuenta de ella, para representarla.

Ahora bien, esta distinción entre argumental y documental en términos de realidad representada — verdad - y ficción deformante — mentira - es, hoy más que nunca, difícil de sostener. Factores como la intervención del realizador, la variación del comportamiento de los personajes frente a la cámara, las recreaciones y puestas en escena hacen imposible desligar realidad y ficción. Las palabras de Jean Rouch respecto a Crónica de un verano pueden iluminar este punto.

En una de las secuencias más célebres de la película, Rouch le pide a un hombre africano que interprete el significado del tatuaje que una de las protagonistas tiene en su muñeca. El tatuaje, contrario a lo que él pensaba, no era un adorno estético sino una marca del holocausto. La petición de Rouch suscita, de esta manera, una particular situación de diálogo y confrontación que él mismo narra en una entrevista:

Aquello fue una provocación [...] estábamos almorzando ya fuera del Museo de Arte y empezamos a hablar de antisemitismo. Cuando hice la pregunta (sobre aquel tatuaje), el aislamiento y los supuestos culturales emergieron dramáticamente. Antes de ese momento la gente estaba jovial y riendo. De pronto los europeos empezaron a llorar y los africanos quedaron totalmente perplejos, pensaban que el tatuaje era un tipo de adorno. Quedamos todos profundamente afectados. El camarógrafo, que era uno de los mejores documentalistas, estaba tan afectado que el final de la secuencia está fuera de foco. Paré la filmación para dar a todos la oportunidad de recobrarse.

Lo interesante de la secuencia es que la situación particular registrada en la imagen no habría tenido lugar sin la intervención directa del realizador, el cual funciona como una especie de detonante dramático de la realidad. Este hecho causó múltiples reacciones debido a que la película fue vista en muchos círculos como la más fuerte renovación del cine verdad (cinéma vérité) planteado en los veinte por Dziga Vertov. La intervención directa del realizador sobre la realidad parecía ir en contra del carácter de verdad de la imagen, tal como lo plantean los interlocutores de Rouch en la entrevista anteriormente citada:

Señor Rouch, usted es muy conocido en Estados Unidos por Crónica de un verano, pero ocurre que cuanto más sabemos sobre este film que inició el cine-verdad, más controvertible nos resulta. Por ejemplo, algunos de sus propios comentarios después de la proyección en el Museo de Historia Natural provocaron cuestionamientos sobre la fundamental «verdad» del film. Usted afirmó que las escenas de las secretarias fueron rodadas en las oficinas de Cahiers du Cinéma. También habló de los individuos del film, muchos de los cuales iban a convertirse en realizadores cinematográficos y otros, como Regis Debray, serían prominentes personalidades del marxismo.

La aparente objeción apunta al centro del problema que aquí tratamos: la relación entre la imagen y la realidad. Ahora bien, la intervención de Rouch no implica una mentira o manipulación de la realidad. La provocación, como él mismo la llama, más que trastocar una realidad verdadera funciona como productora de lo real: «si éste es un momento 〈verdadero〉 o un momento 〈armado〉 — dice Rouch—, ¿tiene alguna importancia?». 
Al igual que Rouch, muchos otros autores han señalado la compleja relación entre el documental y la objetividad. La intervención del realizador es inevitable y define directamente el carácter ontológico de la imagen: «El hecho de mirar el mundo a través de un aparato óptico a través del que se encuadra la realidad, ya posee en sí una dimensión subjetiva muy fuerte. Es imposible separar el documental de la subjetividad. Es ontológicamente imposible» (Guimaraes, 325).

De esta manera, puede comprenderse el eje de la distinción ontológica entre ficción y documental. El carácter de documento de la imagen no se refiere a una correspondencia directa con lo real. La imagen documental supone, al igual que el argumental, un cierto nivel de ficcionamiento de lo real. Lo que muestra Rouch al hablar de la provocación o Guimaraes al enfatizar en la subjetividad es que la realidad no es el punto de partida de la imagen documental, sino su punto de llegada, su producto.

El documental dejaría de ser entendido como registro de lo real para comprenderse como productor activo de realidad. Propongo, entonces, que nos quedemos, en este sentido, con la «definición» aportada por Bill Nichols: «El documental: una ficción (en nada) semejante a cualquier otra» (Nichols, 167).

Si aceptamos, hasta aquí, que el documental no es lo otro de la ficción sino un tipo particular de ficción, tendríamos que optar por encontrar su distancia respecto al cine argumental en las herramientas y procedimientos a través de los cuales se construye dicha ficción. De la distinción ontológica pasaríamos a una distinción de lenguajes.

Este tipo de distinción supondría que ciertas herramientas narrativas y formales son exclusivas del documental frente a la ficción. Así, elementos como cierto manejo de cámara — casi siempre cámara al hombro-, un montaje dirigido más a la argumentación y exposición que a la narración, la presencia del realizador en la imagen - bien sea a través de la voz en off o de su aparición directa-, el uso de documentos de archivo de distinta naturaleza, se han identificado como propios del terreno del documental. Lo que se trata de señalar en últimas con esta separación, es que mientras el lenguaje del llamado cine «argumental» está dirigido a componer una narración, un argumento como su mismo nombre lo indica, el lenguaje documental tiene una finalidad informativa que lo define - argumentativa más que argumental. De acuerdo a estas finalidades cada tipo de audiovisual ha configurado una gramática propia que lo hace distinguible a los ojos del espectador.

Esta distinción, si bien pudo sostenerse durante algún tiempo, resulta hoy totalmente obsoleta. Muchas películas han realizado una mezcla de los elementos que, supuestamente, distinguían documental y ficción: desde The Blair Witch Project hasta los experimentos en video de Jean-Luc Godard, pasando por un sinfín de películas alrededor del mundo, diversos realizadores han problematizado la exclusividad de ciertos procedimientos audiovisuales dentro del campo de la ficción o del documental. El caso más radical son tal vez los llamados «falsos documentales», los cuales demuestran una absoluta conciencia de ese lenguaje supuestamente exclusivo del documental y su relación directa con la percepción de una imagen-verdad.

Este problema se agudiza si se tiene en cuenta que muchos documentales «no convencionales» han experimentado formal y narrativamente no solo con los elementos del argumental, sino con herramientas de otras expresiones literarias y artísticas que pasan por la danza, el ensayo literario, el videoarte, la plástica y la música. Basta citar un ejemplo. En el 2005 los documentalistas Fausta Quattrini y Daniele Incalcaterra realizan 
Contra-site, una película sobre la identidad de Ernesto «Che» Guevara. El hecho central que sirve como eje del documental es una serie de excavaciones que buscan encontrar el cuerpo del Che asesinado en Bolivia por sus captores en los años sesenta. Ahora bien, el espectador tiene acceso a la gran mayoría de las imágenes del documental a través de un computador, pues el eje narrativo de la película es el montaje de un sitio Web dedicado al Che Guevara y a la transmisión en directo de las excavaciones. Así, asistimos a la búsqueda del cuerpo y a la reconstrucción de su figura histórica, pero a través de una serie de reflexiones de diversos personajes ficticios relacionados con el montaje del site. De esta manera, el hecho a documentar aparece mediado tanto por la ficción de los personajes como por el estilo formal de las imágenes digitales para la red. Así, el lenguaje del documental se mezcla con la ficción y con las imágenes de los medios digitales hasta el punto de hacerse indiscernible de ellos. "Yo diría — dice Incalcaterra al respecto- que hoy en día estamos viviendo un momento de contagio de estilos y formatos. Pienso que en la película lo interesante es la mezcla de distintos estilos y uno tiene dificultad para separarlos. Y lo que nos propusimos con Fausta fue justamente crear una sensación de ambigüedad en el espectador; que uno no entienda o no esté seguro sobre qué es realidad y qué ficción. Tanto elementos de ficción y de realidad conviven en la película».

Si nos atenemos, entonces, al panorama del documental contemporáneo en el que es imposible distinguir un lenguaje propio del documental frente a uno del argumental, esos elementos de construcción de la ficción que mencionábamos antes - ya sea ficción argumental o ficción documental- se hacen indiscernibles. Es precisamente hoy cuando estas distinciones, tanto ontológicas como de lenguajes, se hacen inoperantes en el amplio terreno del audiovisual, que nos vemos obligados a preguntarnos dónde se ubicaría la delgada línea que aún distingue documental y argumental, o si, por el contrario, habría que olvidar definitivamente tal taxonomía y empezar a hablar de una especie de «audiovisual total» en el que el asunto de la realidad y la ficción ha quedado superado, voluntaria o involuntariamente.

Ahora bien, el hecho de descartar una perspectiva ontológica y una de lenguaje como medios para definir una frontera entre realidad y ficción no implica necesariamente la obsolescencia de la distinción entre dichos términos. No es mi intención aquí apostar por una identidad absoluta que desemboque en afirmar que «lo real» no existe y que, en tanto habitamos ficciones, estamos destinados al reino del subjetivismo. Sin lugar a duda hoy, igual que siempre, es posible distinguir «lo real» de «lo ficticio», aquello que constituye nuestro presente particular y que aceptamos como verdadero. Hoy seguimos hablando de imágenes reales, verdaderas, así como de «montajes» que identificamos con mentiras. Exigimos a los noticieros veracidad y objetividad, y los criticamos por escondernos la verdad de lo que pasa en el mundo. Admiramos las películas que pueden mostrarnos la realidad de un país, o nos oponemos a ellas por reducirla a fenómenos particulares, casi siempre relacionados con la violencia. ¿Debemos seguir oponiéndonos a la ficción en pos de la verdad en la imagen? O, por el contrario, ¿debemos afirmar que toda imagen es un engaño resignándonos a que sólo accedemos a lo verdadero mediante otros medios más sublimes?

Más que tratar de eliminar las fronteras entre la realidad y la ficción, y por lo tanto entre el documental y el argumental, me interesa preguntarme qué es lo que hace que sigamos llamando a una imagen «documental»: a través de qué operaciones una imagen se legitima a sí misma como real; qué estrategias retóricas son las que, en nuestra época, 
determinan la veracidad de una imagen. Qué constituye nuestra voluntad de verdad. Si lo real es una ficción debemos deconstruir — no destruir- esa ficción. Tal vez así encontremos un tercer punto de vista que permita pensar la frontera entre la realidad documental y la ficción.

\section{FENÓMENOS CONTEMPORÁNEOS QUE REDEFINEN LAS FRONTERAS: LA OMNIPRESENCIA DE LA IMAGEN O EL DEVENIR IMAGEN DE LO REAL}

Si nuestro interés radica en plantear la posibilidad de un tercer punto de vista —más allá de la ontología y el lenguaje- desde el cual pueda pensarse la frontera entre documental y ficción, es necesario reconocer una serie de fenómenos que definen directamente la producción de documentales hoy. El panorama, sin embargo, es bastante amplio. Los cambios tecnológicos, las nuevas dinámicas de producción, los novedosos espacios de difusión y transmisión, el nacimiento de lenguajes audiovisuales inéditos, son factores extremadamente amplios que se relacionan, de una u otra manera, con la situación actual del documental. No es mi interés intentar abarcar cada uno de estos aspectos, sino más bien centrar nuestra atención en un fenómeno particular derivado del desarrollo de las tecnologías de la imagen ${ }^{1}$.

Diversos autores han señalado la aparición del video, y más tarde del video digital, como uno de los acontecimientos más relevantes dentro del desarrollo del documental: la ampliación del ratio de grabación, la portabilidad de los equipos, la reducción de costos, las facilidades técnicas de grabación y edición, entre otros aspectos, componen lo que se ha denominado la «democratización» de la imagen característica de nuestra época.

Ahora bien, esta democratización de la imagen no implica solamente que la realización de documentales sea cada vez mayor por parte de aquellos interesados explícitamente en hacerlo - ya no solo documentalistas y realizadores de medios audiovisuales, sino también estudiantes de diversas áreas, profesionales de distintos campos, e incluso directores «aficionados» a través de cámaras caseras-, sino, sobre todo, una multiplicación de la posibilidad de registro de realidades particulares a través de la imagen. A todas las mejoras mencionadas anteriormente con respecto a la producción de documentales habría que sumar un aspecto que define a nuestra época más que a ninguna otra y que determina directamente la producción audiovisual contemporánea: la existencia de un stock de imágenes que parece agotar la totalidad de la realidad conocida.

Desde las cámaras de video portátiles —empezando por las cámaras de seguridadhasta las pequeñas cámaras incorporadas a diversos dispositivos tecnológicos como los celulares, los reproductores de música y video, los computadores portátiles, etc., es posible encontrar hoy una asombrosa cantidad de mecanismos de registro de lo real. Esta amplificación inédita de la tecnología del video — asociada a la generación de nuevos medios de difusión - ha conseguido que cada vez existan más imágenes de los acontecimientos que componen una realidad determinada. Parece que hoy nada escapa al registro de la

No quiero decir con esto que se trate del único fenómeno relevante para pensar el documental hoy. Al contrario, considero que es una pequeña parte del conjunto de aspectos que deben pensarse con el fin de componer un panorama serio del documental, no solo en términos generales, sino sobre todo en el contexto latinoamericano. 
imagen: desde los hechos mínimos que componen la existencia cotidiana de los individuos hasta los grandes sucesos que afectan, de uno u otro modo, a la población de una amplia región. Es suficiente recordar el video, grabado con un celular, de la ejecución de Sadam Hussein en el 2006 en medio de fuertes dispositivos de seguridad. La grabación se encuentra hoy en cualquier portal de videos de Internet al lado de cientos de registros de hechos de todos los tipos: accidentes, suicidios, apariciones fantasmales, operaciones militares, festivales locales; todos los acontecimientos se colocan al mismo nivel ante el registro de la cámara. Hoy estamos acostumbrados a que cada hecho venga con una imagen de sí mismo. Nuestra experiencia de lo real está cada vez más mediada por las imágenes de registro; no sólo nuestra experiencia de acontecimientos extraños y lejanos, sino incluso de lo más cotidiano. Salimos a la caza de lo real armados con una cámara de celular esperando que el acontecimiento se produzca en la imagen misma. Los noticieros de televisión dan fe de ello.

En el 2007 un noticiero de televisión en Colombia dedicó varios reportajes a lo largo de una semana para informar sobre supuestas apariciones fantasmales en un parque de la ciudad de Cúcuta. Lo particular de la «noticia» es que los registros del fantasma habían sido obtenidos con una cámara de celular por uno de los habitantes del barrio. Una vez difundido el video por televisión nacional, un centenar de habitantes de la ciudad salieron de noche al parque, no solo para ver al fantasma, sino para capturarlo: armados con sus celulares, esperaron horas hasta obtener imágenes de la aparición, las cuales se multiplicaron exponencialmente a lo largo de la semana. Independientemente de si este tipo de imágenes son montajes o no, lo que se hace evidente es cómo se ha creado una indisoluble relación entre la imagen de registro y la realidad.

Así, cada hecho, cada acción en el momento mismo de su ejecución existe a la vez como imagen, hasta el punto de volverse indiscernible de ella. Este hecho ya había sido diagnosticado por Guy Debord en 1967 a través del concepto de espectáculo. El problema de este texto queda quizás resumido en el epígrafe de Feuerbach citado por Debord: «Y sin duda nuestro tiempo [...] prefiere la imagen a la cosa, la copia al original, la representación a la realidad, la apariencia al ser [...] lo que es «sagrado〉 para él no es sino la ilusión, pero lo que es profano es la verdad». Lo que ocurre en nuestra época es que estas fronteras que le permitían a Feuerbach hablar aún del ser real y de la apariencia ficticia se han diluido. El problema ya no es cómo se hace pasar una apariencia por ser -falso problema que muchos han señalado respecto a los nuevos medios- sino cómo el ser ha devenido absolutamente aparente. La situación de la imagen en nuestra época ya no puede pensarse en términos duales de verdad y mentira, realidad y ficción. El problema es cómo, en la época de la omnipresencia de la imagen, lo real mismo deviene ficción.

Allí donde el mundo real se cambia en simples imágenes — afirma Debord—, las simples imágenes se convierten en seres reales y en las motivaciones eficientes de un comportamiento hipnótico. El espectáculo, como tendencia a hacer ver por diferentes mediaciones especializadas el mundo que ya no es directamente aprehensible, encuentra normalmente en la vista el sentido humano privilegiado que fue en otras épocas el tacto; el sentido más abstracto, y el más mistificable, corresponde a la abstracción generalizada de la sociedad actual. Pero el espectáculo no se identifica con el simple mirar, ni siquiera combinado con el escuchar. Es lo que escapa a la actividad de los hombres, a la reconsideración y la corrección de sus obras. Es lo opuesto al diálogo. Allí donde hay representación independiente, el espectáculo se reconstituye. 
El problema, tal como lo señala Debord, tiene que ver con las mediaciones; y hoy, la presencia de las mediaciones posibles se ha multiplicado haciendo que lo real no sea la finalidad y la imagen el medio, sino que podamos hablar de la imagen misma como medio y fin; como productora de lo real.

De esta manera, la omnipresencia de la imagen que define a nuestra época ha conseguido que todo acontecimiento, y esto es toda imagen, sea susceptible de convertirse en documento. La referencia y comparación con los medios masivos de comunicación puede sernos útil nuevamente para comprender la particularidad del documental.

Los medios masivos de comunicación utilizan permanentemente imágenes grabadas por «aficionados» a través de cámaras caseras o celulares para componer sus noticias y difundirlas al mundo. Ahora bien, quisiera señalar precisamente esta curiosa separación creada por los mismo medios entre imágenes «aficionadas» e imágenes "profesionales». ¿En dónde puede radicar el criterio de tal distinción? Indudablemente no se trata de un problema de calidad de registro o incluso de composición de la imagen pues en muchos casos la imagen registrada por un camarógrafo profesional no se distingue de la de un individuo cualquiera en medio de la calle. Tiendo a pensar que lo que los medios llaman imagen «aficionada» hace referencia a lo que ellos mismos denominan «imagen sin editar». El trabajo de un noticiero se ha convertido cada vez más en una labor de montaje frente a las imágenes registradas por un aficionado cualquiera.

El noticiero de televisión citado anteriormente por el caso de las apariciones fantasmales publicó también a mediados de este año uno de los videos más famosos no sólo en Colombia sino a nivel mundial: el «detrás de cámaras» de la célebre Operación Jaque -misión de inteligencia militar con la cual fueron liberados 15 secuestrados en poder de las FARC. El video no fue grabado por un camarógrafo «profesional» de noticias RCN, sino por los mismos militares que hicieron parte de la misión. El noticiero, sin embargo, no trasmite el video «en bruto", sino que lo edita introduciéndolo con una presentación oral, acompañándolo de música — con la canción Wherever I may roam de Metallica-, difuminando los rostros, creando disolvencias entre las fotografías y, obviamente, con un título en la esquina superior derecha de la pantalla con la palabra «exclusivo». Las palabras pronunciadas por las presentadoras en el avance informativo son la mejor muestra de este ejercicio de ensamblaje de imágenes:

La historia completa de la más exitosa y arriesgada operación militar contra las Farc: La «Operación Jaque». Noticias RCN tiene las imágenes que el mundo quería ver, la planeación, los ensayos, el minuto a minuto de la mañana del 2 de julio pasado, cuando un comando élite del Ejército rescató a Íngrid Betancourt, 3 técnicos estadounidenses y 11 militares secuestrados por el grupo rebelde. Las imágenes revelan el ingenio, el talento y el magnífico trabajo de inteligencia que permitió llegar al corazón de las Farc y arrancarles a 15 de sus víctimas.

Ahora bien, en una charla en la Universidad Javeriana de Bogotá, el artista Lucas Ospina recordaba cómo en el 2002 los medios registraron una operación de características similares usando también los videos realizados por sus ejecutores. Se trataba del secuestro de doce diputados del Valle del Cauca por parte de las FARC realizado en abril de 2002, hecho que fue registrado en su totalidad por los guerrilleros que participaron en él. De la misma manera que con la Operación Jaque, los noticieros difundieron la noticia a partir de un ejercicio de montaje de las imágenes, esta vez realizadas por las FARC. Obviamente, la presentación que acompañaba el video era totalmente diferente: la voz 
en off no utilizaba ningún elogio a quienes ejecutaron la misión, el título de «exclusivo» en la esquina de la imagen era reemplazado por uno que advertía que esas imágenes pertenecían a un video de las FARC, y no había una canción de hard rock que exaltara los acontecimientos vistos en la imagen.

Lo que me interesa señalar es que ese amplio stock de imágenes a nuestra disposición, esa diversa realidad devenida imagen se convierte en documento en el momento en que se ensambla, en que se inserta dentro de una retórica particular. Lo real se produce como un efecto de montaje.

A pesar de que Debord no habló explícitamente de montaje, ya señalaba la particular operación de unión realizada por el espectáculo:

El origen del espectáculo es la pérdida de unidad del mundo, y la expansión gigantesca del espectáculo moderno expresa la totalidad de esta pérdida: la abstracción de todo trabajo particular y la abstracción general del conjunto de la producción se traducen perfectamente en el espectáculo, cuyo modo de ser concreto es justamente la abstracción. En el espectáculo una parte del mundo se representa ante el mundo y le es superior. El espectáculo no es más que el lenguaje común de esta separación. Lo que liga a los espectadores no es sino un vínculo irreversible con el mismo centro que sostiene su separación. El espectáculo reúne lo separado, pero lo reúne en tanto que separado.

Mi propuesta radica en pensar que, en esta época de la imagen omnipresente, el montaje, esa lógica de asociación que parece ser el centro de la sociedad espectacular, es uno de los aspectos centrales para pensar la producción documental contemporánea.

\section{HACIA UNA PERSPECTIVA ÉTICA [POLÍTICA] DEL DOCUMENTAL: LA CEN- TRALIDAD DEL CONCEPTO DE MONTAJE}

El cine documental no ha permanecido ajeno a esta sobresaturación de imágenes de registro que caracteriza nuestra época. Al igual que los noticieros de televisión, algunas películas se han servido de imágenes pre-grabadas a través de dispositivos de distinta naturaleza para componer una narración documental.

Uno de los mejores ejemplos es el documental Onibus 174 realizado en el 2002 por el brasileño José Padilha. La película cuenta el secuestro de un bus en la ciudad de Río de Janeiro ocurrido el 12 de junio de 2000. Todo el hecho fue registrado en vivo por la televisión y es, precisamente, con estas imágenes con las que Padilha compone su película realizando una reconstrucción del acontecimiento.

Este tipo de composición parece, sin embargo, no ser novedoso en la historia del cine. El uso de imágenes de archivo ha sido recurrente en el documental. En 1995 el director y antropólogo holandés Vincent Monnikendam realiza Mother Dao con forma de tortuga, un documental acerca de las colonias holandesas en Indonesia. El filme está compuesto a partir de imágenes tomadas por los colonizadores holandeses entre 1912 y 1933 con el objetivo de mostrar cómo las colonias eran gobernadas de manera benevolente sobre todo en el ámbito de lo social. Se trataba de imágenes legitimadoras, que buscaban celebrar la obra civilizadora de Holanda sobre pueblos salvajes. Monnikedam retoma dichas imágenes —extraídas de más de 200 películas_- y las reorganiza intentando mostrar 
una especie de felicidad oculta en los nativos frente a los ejercicios impuestos por los colonizadores, una especie de orgullo irónico por prestarse al juego de ser colonizados. Jean-Luc Godard realiza sus Histoire(s) du cinéma a finales de los noventa a partir de la recomposición de fragmentos de diversas obras de la cinematografía mundial mezclados con textos, citas sobre pantalla, fotos, cuadros, fragmentos musicales, sonidos, y narraciones en off. En los años veinte Dziga Vertov, ante la escasez de película para filmar ocasionada por la guerra civil, propuso la realización de films de montaje. A esta nueva práctica Vertov la denominó el cine-objeto: el cineasta podía componer películas utilizando fragmentos de films registrados por otros, montando y ensamblando objetos seleccionados pero no creados por el mismo realizador.

Este énfasis en el montaje de material ya filmado como eje estructural del documental adquiere hoy más relevancia que nunca. Hoy, en el momento en que la tan mencionada democratización de la imagen ha hecho casi irrelevante quién y cómo se consiga un registro de los acontecimientos. Hoy, cuando lo real mismo ha devenido imagen, nuestra reflexión no puede seguir apuntando a preguntar por la verdad de lo registrado - los límites entre verdad real y mentira ficticia han desaparecido-, sino a indagar esos ejercicios de ensamblaje desde los cuales se nos construye una realidad, ese montaje a través del cual la imagen de registro adquiere consistencia como documento.

Si bien el cine documental comparte el principio de montaje como articulador de la imagen con los noticieros de televisión, las notas periodísticas y cualquier otro discurso que intente dar cuenta de lo real, podríamos afirmar que existe una diferencia fundamental. En ella podría radicar la especificidad del documental que tanto hemos buscado desde el inicio de esta reflexión.

Guy Debord nos mostró cuál era el principio de montaje propio de la sociedad espectacular: la unión de lo separado, en tanto separado. Ahora bien, la particularidad del documental puede radicar en proponer otro tipo de montaje diferente al principio de ensamblaje de la sociedad espectacular ${ }^{2}$.

La importancia del montaje en el cine documental no es algo nuevo en ningún sentido. Los «pioneros» del documental como Robert Flaherty y Dziga Vertov ya afirmaban la necesidad de la selección y yuxtaposición de imágenes. Para Flaherty, por ejemplo, la función del documentalista no se reducía a filmar los hechos, sino que parte central de su trabajo era la selección: «La selección subsiste, y tal vez de forma más rígida que en los mismos filmes de espectáculo. Nadie puede filmar y reproducir, sin discriminación, lo que le pase por delante, y si alguien fuese lo bastante inconsiderado como para intentarlo, se encontraría con un conjunto de fragmentos sin continuidad ni significado, y tampoco podría llamarse film a ese conjunto de tomas» (Flaherty, 78).

Medio siglo más tarde, en un texto de 1995, Jean-Luc Godard enfatiza también la importancia del montaje, aunque su tono cambia radicalmente. Godard afirma, de manera radical y casi violenta, que el cine como medio de expresión ha fracasado drásticamente: «todo acabó desde el momento en que no se filmaron los campos de concentración» (cit. en Didi-Huberman, 208). Ahora bien, lo que llama la atención de la sentencia de Godard es que contrasta directamente con la existencia de varias series de imágenes de registro filmadas en la época del nacionalsocialismo alemán por diversos cineastas e incluso por los mismos militares. Habría que pensar, entonces, que cuando Godard afirma que el

Distinguiré, entonces, entre «ensamblaje», para designar las dinámicas de conjunción de la sociedad del espectáculo, y «montaje», refiriéndome a los procedimientos propios del cine, en este caso del documental. 
cine dimitió en su misión expresiva, señala, precisamente, que el hecho de que existan imágenes de registro del holocausto no es suficiente para afirmar que el cine ha mostrado lo que ocurrió en los campos. Que el cine no haya filmado los campos se refiere a que no se han sabido montar las imágenes de registro existentes; a que una serie de imágenes sueltas no son cine, y que es en el principio de su ordenamiento y yuxtaposición donde radica su poder de mostrar. Lo que me interesa resaltar de la afirmación de Godard es que la capacidad del cine de dar cuenta de la realidad de los campos no depende de un ejercicio técnico, de filmación o de edición. El punto no es que las imágenes filmadas no se hayan montado, sino que no se han sabido montar. Es evidente, entonces, que Godard apunta a diferenciar dos tipos de montaje, desde la perspectiva de la capacidad de la imagen de mostrar lo real.

Ahora bien, la diferencia entre estos dos tipos de montaje no es del todo clara en las palabras de Godard. Georges Didi-Huberman cree que se trata de un asunto de justicia. El montaje puede componer una imagen justa o injusta de lo real: «tal como un filme de ficción — siguiendo la visión que tienen de éste Hitchcock, Godard, Bresson y muchos otros- puede llevar las imágenes a un grado de intensidad capaz de hacer surgir de ellas una verdad, también un simple telediario puede utilizar unas imágenes documentales hasta llegar a producir una falsificación de una realidad histórica que, sin embargo, archivan» (Didi-Huberman, 202). Tendríamos, entonces, un montaje justo diferenciado de uno injusto.

Al plantear el problema en términos de justicia nos desplazamos inmediatamente al terreno ético, en el cual puede ser posible descifrar la distancia entre las imágenes injustas del ensamblaje espectacular y las imágenes justas del montaje cinematográfico. Ahora bien, debemos comprender en qué sentido se habla de justicia e injusticia; justo o injusto respecto a qué.

En primer lugar podríamos pensar que esta justicia se refiere a una relación particular con el acontecimiento a documentar. Una imagen es justa en la medida en que muestra el acontecimiento; es injusta en la medida en que lo falsifica. Ahora bien, no podemos olvidar que esta justicia de la imagen no debe ser comprendida en términos de correspondencia. Una imagen documental no es justa en el momento en que se corresponde con la realidad, en que la representa fielmente. Más que de una correspondencia justa, estamos hablando desde un principio de una ficción justa. Ahora bien, ¿cómo puede ser justa una ficción si de entrada supone una alteración, una deformación del acontecimiento «original»; un montaje del mismo? Usemos un ejemplo concreto: entre 1971 y 1974 el director brasileño Glauber Rocha realiza un documental titulado Historia do Brasil. Se trata de un largometraje de dos horas y cuarenta y seis minutos de duración compuesto por documentos de archivo de diversa índole acompañados por una voz en off que narra y organiza los distintos acontecimientos. Acerca del montaje de la película, la cubana Mirian Talavera narra, en tono coloquial, una interesante anécdota:

Empecé con él, íbamos a hacer supuestamente una historia del Brasil. Cuando llegué al cuarto de edición encontré que tenía una cantidad enorme de materiales, de archivos, fotoanimaciones, trucajes, todo tipo de película. Porque realmente materiales sobre Brasil, tenía poco. Entonces tuvo que reconstruir a través de fotos, de periódicos y documentos. Yo estaba rodeada de cajones con películas. Entonces dije: «Bueno, vamos a empezar. ¿Cómo vamos a hacer?». Y Glauber agarra una cajita de fósforos y se ponía detrás de mí, así, con la cajita, y empieza como a sambar detrás de mí. Él iba cantando, supongo yo, 
cosas que tendrían que ver con lo que él estaba haciendo; eran cosas que lo inspiraban. Eso a mí me daba mucha risa, porque yo esperaba que me dijera qué iba a hacer. Entonces, en un momento determinado le digo: «Monté una cosa que estaba más o menos [...] una fotoanimación que tenía más o menos una coherencia y, bueno, yo sabía como hacerla», pero ya cuando tengo que pasar a otra cosa pues le digo: ¿Y ahora qué viene?». Y me dice: «Lo que tú quieras». Digo: «No, ¿cómo va a ser lo que yo quiera si estamos haciendo la historia de Brasil, y yo no me la conozco? Me tiene usted que ayudar». Me dice: «No, la historia de Brasil no existe. La vamos a escribir ahora. La vamos a hacer ahora entre tú y yo» (Rocha, Rocha que voa).

El problema que se plantea es evidente: ¿cuál es la validez histórica de una serie de imágenes que no toman como criterio el «verdadero» devenir de los acontecimientos en el Brasil? Ahora bien, supongamos por un instante que podemos obviar el asunto de la validez y veracidad del montaje de la Historia do Brasil, y fijarnos en el señalamiento que realiza el director brasileño sobre la imposibilidad de pensar un criterio de montaje y construcción de la imagen cinematográfica basado en la correspondencia con un objeto exterior a la imagen misma. La organización de las imágenes no se comprende como un ejercicio de representación fidedigna de lo otro, sino como producción activa del acontecimiento. El montaje, en las palabras de Rocha, se convierte en una escritura de lo real, en la creación de una ficción en la que aparecerá la historia. De esta manera la pregunta por la validez no desaparece, pero debe reformularse en sus términos. Rocha no está insinuándole a su montajista que mientan en la composición de las imágenes, que falsifiquen los acontecimientos. Lo que señala es que los hechos acontecidos en el Brasil a lo largo del tiempo no existen como historia, no han sido montados como tal; por eso, precisamente, se hace necesaria una escritura, una ficción. Sólo pensándose como ficción, la tarea de reconstrucción a partir de archivos emprendida por Rocha y Talavera puede ser justa con aquella historia que busca recuperar.

Ahora bien, ¿no sigue siendo paradójico pensar que es en el montaje de una ficción, es decir, en la producción de una absoluta distancia con respecto al mundo real, en donde la imagen puede ser justa con ese mismo mundo? ¿Cómo debe ser ese montaje que consigue una imagen justa?

Las primeras dos cuestiones apuntan directamente al asunto del realismo: cómo se puede hablar de realidad en la imagen si, como plantea el cineasta y teórico francés JeanLouis Comolli, es en el retiro del mundo donde se levanta el telón de la representación. Ahora bien, tal como lo plantea indirectamente Glauber Rocha al hablar del montaje, la relación de este último con lo real debe ser comprendida en términos de producción. Comolli señala cómo la noción misma de «puesta en escena» supone ya la puesta en duda del mundo y su puesta en abismo como escena, es decir, la imagen se vuelve el «mundo» en el cual se inscribe la imagen misma, el mundo-como-imagen. Esto no quiere decir que no exista un mundo a ser filmado. Sin embargo, éste actúa solamente como la materia prima de la imagen, pero no como la realidad en la que ésta se inscribe. El neorrealismo italiano aplicó permanentemente este principio: la imagen surge cuando la realidad se ha hecho violentamente inaprensible, cuando ha desaparecido para los sujetos. Edmund, el niño de Alemania, año cero, por ejemplo, encarna esta pérdida. Se trata de un personaje totalmente dislocado de lo real. Ha perdido, gracias a la guerra, su condición de infante e intenta, desesperadamente, encajar en la adultez que le exige su entorno. Sin embargo, nunca lo logra y termina por dejarse caer al vacío después de divagar por las calles de una Berlín igualmente agujereada. La imagen de Edmund es precisamente la conciencia 
de una época de aquella pérdida de realidad. El cine aparece, no para devolver la realidad a los sujetos en una especie de terapia audiovisual, sino para mostrar las huellas de la pérdida. Éste es el neo-realismo: «un realismo en el que las marcas de las realidades desaparecidas se hacen hiperreales» (Comolli, 189).

Habría que comprender, entonces, que es solo en la retirada del mundo en la imagen, donde se hace justicia a ese mundo. Ésta es la potencia de la ficción: «el mundo no es exaltado: necesita del cine para serlo, necesita de eso mismo que lo mina, lo pone en duda y en ausencia (hasta reemplazarlo en el ínterin de una sesión)» (Comolli, 251).

Recapitulemos: al preguntarnos por la particularidad del cine documental hoy, enfrentándolo al cine argumental, afirmamos la imposibilidad de sostener una perspectiva ontológica o una de lenguajes para trazar la frontera entre estos dos «tipos» de imagen. El documental se nos revelaba como un tipo particular de ficción y no como lo otro de la ficción. Ahora bien, en nuestra época la construcción de esta particular ficción documental se enfrenta a la omnipresencia de la imagen: lo real en su totalidad parece estar a nuestra disposición como imagen de registro. De esta manera, la tarea de componer un documento, de construir una realidad en la imagen se convierte, en parte, en un ejercicio de articulación de imágenes pre-existentes. Así lo hacen evidente los noticieros y las notas periodísticas, pero también una diversidad de films documentales. Si aceptamos, por un lado, que el documental no es un registro objetivo de lo real, sino una ficción particular que construye realidad; y, por otro lado, que dada la saturación de imágenes en la que vivimos la construcción de realidades depende de ejercicios retóricos de montaje; debemos preguntarnos en qué consiste la particularidad del montaje documental que lo diferencia de otras formas de composición y narración con imágenes, de otras formas de construcción de lo real — particularmente de aquella que hemos llamado con Debord «sociedad del espectáculo»- Esta diferencia solo puede definirse como un asunto ético: el montaje compone lo que hemos llamado una «ficción justa» mientras el ensamblaje espectacular es injusto con el acontecimiento que intenta mostrar.

Ahora bien, queda aún por resolver la cuestión de cómo debe ser concretamente la forma de aquel montaje que distancia a la imagen documental del ensamblaje espectacular consiguiendo una ficción justa. Una nueva anécdota, narrada por Didi-Huberman respecto a Alfred Hitchcock, puede ofrecernos un posible camino de resolución: en 1945, una vez las fuerzas aliadas habían ingresado a los campos de concentración instaurados por el nacionalsocialismo alemán, el mundo tuvo a su disposición un considerable cuerpo de imágenes rodadas en los campos. Muchos cineastas fueron consultados por las fuerzas militares sobre el posible uso de estas imágenes, como fue el caso de John Ford en Norteamérica. En Inglaterra Alfred Hitchcock fue consultado por su amigo y cineasta Sydney Bernstein sobre el mismo asunto: cómo montar estas imágenes. "Hitchcock entendió inmediatamente - dice Didi-Huberman- que esta forma exigía un montaje que no separase nada: en primer lugar, era necesario no separar las víctimas de los verdugos, es decir, había que mostrar juntos los cadáveres de los prisioneros bajo la mirada de los propios responsables alemanes [...] Luego era necesario no separar el propio campo de su ambiente social, fuera éste normal, bonito, rural, e incluso bucólico» (Didi-Huberman, 203).

La pregunta es, entonces, cómo puede entenderse este montaje «que no separa nada» que se opondría al ensamblaje espectacular que «une en tanto separado». Por qué el tipo de montaje propuesto por Hitchcock sería «justo» con los acontecimientos. 


\section{LA JUSTICIA CON EL ACONTECIMIENTO: EL MONTAJE Y LA VISIÓN}

Es posible, ahora, complejizar esta noción de justicia estrechamente relacionada con un tipo particular de montaje.

La pregunta que puede servirnos como guía es muy simple: ¿por qué Hitchcock pedía un montaje "que no separase nada» frente a las imágenes de los campos de concentración nazis? Si su exigencia se dirigía a que se mostrasen juntas las víctimas y los victimarios, los campos y su contexto, no era por un afán amarillista ni moralizante, sino más bien por un deseo de justicia con la singularidad del acontecimiento. No separar nada a través del montaje no implica ni una denuncia y toma de partido por una de las partes, ni una asimilación total de los elementos singulares. Paradójicamente, esto es lo que consigue el ensamblaje espectacular: la singularidad del acontecimiento se reduce a un hecho de actualidad. En esto radica su injusticia: no en mostrar una imagen que no se corresponde con lo real, sino en reducir una singularidad inscribiéndola en el continuum de sucesos que componen nuestra "actualidad». Contrario a esto, el montaje, al no separar, permite captar la diferencia constitutiva del acontecimiento, las relaciones que lo constituyen. La no separación no equivale a una unificación sino a la exaltación de las diferencias. Al mostrar los campos dentro de su contexto particular se lograba dar cuenta de la particularidad del acontecimiento del holocausto. No se trata de explicar o definir, sino de mostrar la multiplicidad de relaciones singulares que componen esa realidad concreta. De nuevo Jean Rouch puede servirnos como ejemplo.

En 1955 Rouch realiza uno de sus documentales más famosos: Los maestros locos. La película se centra en el registro de un rito realizado por la secta religiosa de los haoukas, en los alrededores de Accra, capital de Ghana ${ }^{3}$. Se trata de un culto basado en danzas de posesión en el que los participantes entran en un trance en el que sus cuerpos son tomados por distintos «maestros», personajes diversos de la colonización africana. Así, el grupo de africanos se transforma, poco a poco, en un grupo de colonizadores compuestos por «el gobernador», «el médico», «la mujer del médico», «el maquinista del tren», «el centinela», entre muchos otros. Para un observador exterior, el rito está cargado de una particular violencia pues, además de los exagerados gestos corporales, la espuma que escurre de sus bocas, y las muestras de posesión a través del fuego quemando el cuerpo, el culto culmina con el sacrificio de un perro del cual todos beben su sangre y comen sus partes. Esto es quizás lo más recordado del documental; la violencia del sacrificio lo hizo famoso en todo el mundo.

Sin embargo, lo más interesante del film no se encuentra allí. Rouch no se limita a filmar la posesión y a resaltar su violencia característica. De hecho, los actos que podríamos considerar más violentos, por ser los que más resultan extraños a nuestras costumbres, nunca se muestran directamente, sino que se insinúan en los movimientos de los individuos. Lo que hace tan interesante la película de Rouch es la manera en que monta el rito, lo que rodea - y se inserta en medio de- el acontecimiento particular. Otras dos secuencias acompañan el registro del culto: una anterior en la que el director introduce la vida de la ciudad, las costumbres cotidianas, el contexto particular de una ciudad colonizada. Y una posterior, el día después del rito, en el que se centra en mostrar cómo

No debe perderse de vista que para la fecha se trataba de una colonia inglesa. La independencia de Ghana sólo se firmó dos años más tarde. 
aquellos personajes que un día antes estaban poseídos y comían de la carne de un animal prohibido, retornan a sus actividades cotidianas como vendedores, obreros o soldados.

Además de estas dos secuencias, dentro del registro del ritual Rouch introduce una imagen singular. En el clímax del rito, en el momento en que todos los «maestros» han comparecido en el lugar, Rouch inserta una imagen de un cambio de guardia de los soldados ingleses en el palacio de gobierno de la ciudad. Por un instante, dos imágenes se nos enfrentan en una especie de espejo siniestro: los soldados ingleses símbolo de la colonización, frente a los negros africanos poseídos por los colonizadores ingleses, ambos dentro de un ritual particular.

De esta manera, el documental no se limita simplemente a registrar el, a nuestros ojos, exótico ritual, sino que devela su singularidad constitutiva al ubicarlo dentro de un contexto. Rouch nos presenta una versión del acontecimiento a través de la cual su singularidad se hace visible — singularidad que supera incluso la interpretación del mismo Rouch, para quien el rito público funciona como una especie de «terapia» que le permite a los africanos enfrentar la colonización dentro de su cotidianidad. El documental no se basa, entonces, en un ejercicio de registro o de representación directa del acontecimiento, sino en un montaje que coloca juntos elementos que permiten mostrar una singularidad no visible. Sergei Eisenstein, en los treinta, definía de esta misma manera la tarea del montaje al compararlo con los ideogramas japoneses: «de la combinación de dos «representables» se logra la representación de algo gráficamente irrepresentable» (Eisenstein, 34).

El montaje no se entiende, entonces, como una fórmula de ensamblaje para representar una realidad, sino como un rodeo ficcional que permite mostrar, pese a su irreductibilidad, la singularidad de lo real —o más bien, lo real en tanto singular.

Lo real no se registra, no se representa. Aparece en la imagen, a través del montaje, como una especie de visión. Tal como lo cree el realizador argentino Fernando Birry, las visiones han sido mal comprendidas. Se piensa comúnmente que tener una visión implica que algo se aparezca ante nuestros ojos materializándose, «un fantasma que se corporiza» dice Birry.

Sin embargo, podríamos pensar en otra comprensión de las visiones: «a lo mejor las visiones son simplemente como sobreimpresiones cinematográficas, que tú tienes cuando piensas en alguna cosa mientras estás, contemporáneamente, mirando la realidad [...] Son como proyecciones de los pensamientos, digamos así, que no alcanzan a tener esa condición de ectoplasmas que se corporizan. Son como pensamientos, como sueños que se sobreimprimen» (Birry, en Rocha que voa). Quizás sea esta la mejor descripción del montaje. La realidad aparece como una visión que no alcanza a materializarse en la imagen, pero que se insinúa en ella como una sobreimpresión ${ }^{4}$.

Es así como podemos comprender la justicia del documental. El montaje no separa, sobreimprime, une para mostrar la diferencia. Es justo con la singularidad absoluta de la realidad documentada. Se trata de una práctica contraria al ensamblaje espectacular

Algo similar es lo que plantea Gilles Deleuze en La imagen-tiempo al definir las diferencias entre dos regímenes de la imagen: el orgánico, cuyas descripciones suponen la independencia de su objeto; y el cristalino, el cual supera los términos de la representación al crear permanentemente su objeto dentro de la misma imagen. Este último régimen, mostrará, para Deleuze, las potencias de lo falso. Mientras el primero se basa todavía en una relación con la verdad en tanto supone un objeto exterior con el que ésta se corresponde, el segundo ha eliminado una aspiración a lo verdadero para hacerse esencialmente falsificante. A este segundo régimen Deleuze lo llama un cine de vidente. 
que compone una actualidad objetiva reduciendo las realidades particulares al unirlas en tanto separadas, al colocarlas a un mismo nivel.

Tal vez este punto sea aplicable no solo para el documental sino para el cine en general, e incluso para la totalidad del arte. Buscando la especificidad del documental a través del concepto de montaje habríamos terminado por igualarlo al hacer del arte en general. Sin embargo, un matiz más se hace necesario.

La particularidad de la ficción documental puede pensarse desde su relación con su «materia prima». Si bien es cierto que el acontecimiento solo se muestra como tal en la imagen, que la realidad no es algo que preexista al documental sino que se produce en él, también debe aceptarse que hay un mundo histórico con el que el documental trabaja en su tarea de hacer visible la singularidad de lo real. Si el documental es una ficción particular no es porque represente la realidad del mundo histórico, sino porque exhibe directamente su materia prima compuesta por un rostro doble: lo existente como tal, el mundo histórico; y las estrategias retóricas a través de las cuales lo existente se revela como real, se hace documento. El argumental también puede dar cuenta del acontecimiento, hacerlo visible. Sin embargo, no revela la misma materia de expresión que el documental. Incluso cuando el argumental trabaja con el mundo histórico lo oculta detrás de las estrategias de la ficción. El documental, en cambio, exhibe su materia y el trabajo de composición que realiza sobre ella. Su punto de partida es una aceptación radical de lo existente. Tal como lo afirma el reconocido documentalista brasileño Eduardo Coutinho, el problema del documental es «filmar siempre el acontecimiento único que nunca ocurrió antes ni jamás volverá a ocurrir. Aunque sea provocado por la cámara. Aunque no sea verdad [...] Sólo se puede subvertir la realidad, en el cine como en cualquier parte, si se acepta antes todo lo existente por el sencillo hecho de existir» (Coutinho, 495). 


\section{REFERENCIAS}

Coutinho, Eduardo. «La mirada en el documental y en la televisión». Cine documental en América Latina. Ed. Paulo Antonio Paranaguá. Madrid: Cátedra, 2003. Medio impreso.

Debord, Guy. La sociedad del espectáculo. Sin dominio. Sitio Web.

Didi-Huberman, Georges. Imágenes pese a todo. Trad. de Mariana Miracle. Barcelona: Paidós, 2004. Medio impreso.

Eisenstein, Sergei. La forma del cine. Trad. de María Luisa Puga. México: Siglo XXI, 2006. Medio impreso.

Flaherty, Robert. «La función del documental». Textos y manifiestos del cine. Ed. Joaquin Romaguera. Madrid: Cátedra, 1998. Medio impreso.

Guimaraes, Cao. «Documental y subjetividad. Una calle de doble mano». Artes y medios audiovisuales: un estado de situación. Ed. Jorge la Ferla. Buenos Aires: Nueva librería, 2007. Medio impreso.

Incalcaterra, Daniele. «Entrevista a Daniele Incalcaterra». Sitio Web. Fecha de ingreso: 28 de mayo de 2010.

Nichols, Bill. La representación de la realidad. Trad. de Josetxo Cerdán y Eduardo Iriarte. Barcelona: Paidós, 1997. Medio impreso.

Rocha que voa. Rocha, Eryk, dir. Act. Santiago Álvarez, Fernando Birri, Julio García Espinosa. Grupo Novo de Cineme e TV, 2003. Medio fílmico.

Rouch, Jean. «Entrevista a Jean Rouch». Antropología Visual. Sitio Web. Fecha de ingreso: 9 de mayo de 2010.

Ruffinelli, Jorge. «Documental político en América Latina: un largo y un corto camino a casa (década de 1990 y comienzos del siglo XXI)». Documental y vanguardia. Eds. Torreiro, Casimiro y Josetxo Cerdán. Madrid: Cátedra, 2005. Medio impreso.

Recepción: 8 de junio de 2010

Aceptación: 9 de julio de 2010 